\title{
MULTI-HAZARD ANALYSIS AND MAPPING OF COASTAL TAURANGA IN SUPPORT OF RESILIENCE PLANNING
}

\author{
Steve C. Raynor ${ }^{1}$ and Megan Boston ${ }^{2}$
}

(Submitted July 2020; Reviewed September 2020; Accepted May 2021)

\begin{abstract}
High growth is increasingly forcing development of hazard prone land in the coastal city of Tauranga. A multi-hazard mapping tool developed to guide strategic growth planning in this natural hazard rich environment gives direct comparison of total hazard levels across the city. By aggregating individual hazards into a summative multi-hazard rating for each part of the city, urban planners and engineers have a decision support tool to aid city planning over the next 100 years.

Tauranga growth requires 40,000 new homes over the next four decades in addition to the existing 57,000 homes. This $70 \%$ growth must squeeze within tight geographic constraints as Tauranga's 137,000 residents nestle around a harbour and are bound by open coast to the north and steep terrain to the south.

This research quantifies Tauranga's natural hazards of sea level rise, storm surge, coastal erosion, tsunami, earthquake shaking, liquefaction, landslides volcanic ashfall and flooding. Each hazard is spatially represented through hazard maps. Individual hazards are combined into a multi-hazard model to represent the aggregated hazard exposure of each point of the city. The multi-hazard exposure is spatially mapped using GIS allowing an area with tsunami, liquefaction and storm surge as dominant hazards to be directly compared with an area of different hazards such as flooding and landslides. Mapping of these hazards provides strategic input for building city resilience through land use planning and mitigation design. A pilot study area of 25 $\mathrm{km}^{2}$ selected from the Tauranga City Council total area of $135 \mathrm{~km}^{2}$ demonstrates the accumulated mapping approach. The pilot area contains a thorough representation of geology, elevation, landform and hazards that occur throughout the city.

Our findings showed the highest aggregated hazard areas in Tauranga are along the coast. As is common with many beach resort towns this corresponds with the most popular living areas. The lower hazard areas suitable for urban growth are distributed mostly away from the open coast in the slightly elevated topography.
\end{abstract}

\section{INTRODUCTION}

\section{Tauranga - A Growing Coastal City}

Good climate, easy beach access and proximity to recreational opportunities makes Tauranga a popular home and the fastest growing city in New Zealand (see Figure 1). This high growth is increasingly forcing development of hazard prone land for accommodation and industry. Growth projections require 40,000 new homes over the next four decades in addition to the current 57,000 homes. This $70 \%$ growth must squeeze within tight geographic constraints as Tauranga's 137,000 residents nestle around the harbour and are bound by open coast to the north and steep terrain to the south.

Typical for a coastal city a significant feature is the shoreline. This includes $26 \mathrm{~km}$ of open coast forming roughly the northern boundary of the city and the harbour coast which comprises multiple headlands, inlets and islands. Half of the inner harbour's $62 \mathrm{~km}$ of shoreline is characterized by $25 \mathrm{~m}$ high cliffs these are typically near-vertical faces which suffer constant erosion.

\section{Tauranga Natural Hazard-Scape}

The predominant sources of natural hazards in Tauranga arise from New Zealand's high level of seismic activity, the Taupo Volcanic Zone (TVZ) to the south and east, Auckland volcanic fields to the west and global sea level rise (SLR).

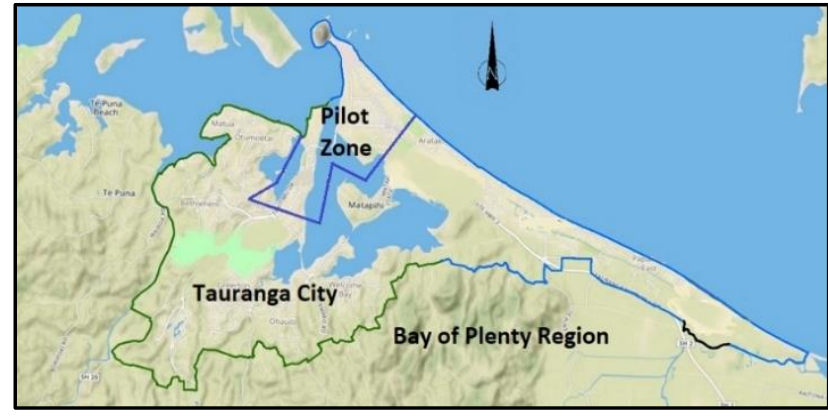

Figure 1: Tauranga is a popular and rapidly growing coastal city in the Bay of Plenty region of New Zealand.

New Zealand is a nation on the move, straddling the Pacific and Australian continental plates. This tectonic interface extends thousands of kilometres north and south of Tauranga and generates hundreds of earthquakes from its annual movement of around $60 \mathrm{~mm}$. The Kermadec and Hikurangi trenches are to the north and east and major seismic movement on these plate interfaces is likely to generate earthquake shaking, liquefaction and tsunami hazards in Tauranga.

The TVZ is one of the most productive on earth in the last 20,000 years. The most recent eruption exceeding $1.0 \mathrm{~km}^{3}$ of ejecta was in 1886 in which Tauranga received a substantial ashfall, however the volcanic sources are far enough away that 
proximal effects such as lava or pyroclastic flows are unlikely. Several of the volcanic cones are constantly active and monitored. White Island was the most recent eruption in December 2019. Multiple fatalities as a result of this eruption highlight the need for natural hazard awareness and education.

As a coastal city with $88 \mathrm{~km}$ of coastline and many low-lying areas the impact of sea level rise will be directly felt by the residents and the infrastructure. The most popular parts of the city are coastal due to their recreational and aesthetic value. A nationwide assessment in 2019 identified \$200 million of Tauranga assets at risk in just $1.0 \mathrm{~m}$ of sea level rise including $13 \mathrm{~km}$ of road and $175 \mathrm{~km}$ of water pipes [1].

\section{Hazard Research and Mapping to Guide Growth Planning}

Managers of growth cities like Tauranga are in immediate need of knowledge and tools to guide development. They are now faced with climate change, sea level rise and intensified storms in addition to the already familiar natural hazards such as floods, volcanoes and earthquakes. From designers to councillors, all need certainty as they make decisions on growth and its attendant investment. These decisions depend on resilience considerations of preparing the city to survive natural hazards, recovering from major events and planning for sea level rise. A deficiency of existing Tauranga hazard data is that it does not fully incorporate sea level rise or forecast sufficiently far into the future to inform decisions that will impact 100 years into the future.

A key tool in evaluating and comparing potential growth areas is the quantification and spatial mapping of the natural hazards. This research has developed an aggregated multi-hazard mapping approach that will contribute to confident strategic growth decisions in Tauranga.

\section{NATURAL HAZARD IDENTIFICATION AND QUANTIFICATION}

This research seeks to accurately quantify and map the major natural hazards Tauranga is exposed to. This will inform city planning and be a pivotal input into building resilience into physical city infrastructure.

Hazards included in this study are sea level rise, coastal inundation from storm surge, coastal erosion, earthquakes, tsunami, liquefaction, landslides, volcanic ashfall and flooding. Hazard research is ongoing with tsunami, flooding and inundation at the open coast due for completion after publication of this paper.

\section{Establishing a Consistent Methodology for All Hazard Studies}

This research established a consistent approach to time horizons, event scenarios and spatial mapping of each natural hazard to enable effective summation into the multi-hazard representation. Time horizons adopted were current, 50-year and 100-year projections. These reflect planning horizons mandated nationally and common infrastructure design return periods.

Geomorphology and sea level rise were identified as key components to several hazard studies and were quantified early and applied consistently across all hazards. Geomorphology was a valuable informant to likely ground behaviour in earthquake shaking, liquefaction and landslip studies. Sea level rise projections informed inundation, erosion, flooding, tsunami and liquefaction studies.

\section{Sea Level Rise}

Mean sea level (MSL) calibration was carried out as a foundational baseline for all future sea level rise measurements and established a rise of $60 \mathrm{~mm}$ since 1995 [2].

Historical sea levels provide confidence in the establishment of the MSL of $0.13 \mathrm{~m}$ (Moturiki 1953 datum) in 2020. The rate of SLR has been analysed by NIWA at nominally $2 \mathrm{~mm} /$ year prior to 2000 and $3 \mathrm{~mm} /$ year since.

Sea level rise in Tauranga is projected from this baseline and adopts four scenarios of global temperature rise out of three greenhouse gas representative concentration pathways (RCP) as determined by Ackerley and Bell in 2013 [3]. Table 1 lists these projections and values adopted for hazard studies following adjustment for timelines appropriate to city planning and rounding for the benefit of community users.

\section{Table 1: Sea level projections showing calculated and adopted values for Tauranga.}

\begin{tabular}{|c|c|c|c|c|c|}
\hline \multirow{2}{*}{ Purpose } & \multirow{2}{*}{ Year } & \multicolumn{4}{|c|}{$\begin{array}{c}\text { Projection Scenarios } \\
\text { based on IPCC } 5\end{array}$} \\
\hline & & $\begin{array}{c}\text { RCP } \\
2.6\end{array}$ & $\begin{array}{l}\mathrm{RC} \\
4.5\end{array}$ & $\begin{array}{c}\mathrm{RCP} \\
8.5\end{array}$ & $\begin{array}{l}\mathrm{RCP} \\
8.5 \mathrm{H}+\end{array}$ \\
\hline Baseline & $1986-2005$ & 0.07 & 0.07 & 0.07 & 0.07 \\
\hline Current & 2020 & 0.13 & 0.13 & 0.13 & 0.13 \\
\hline Calculated & 2070 & 0.39 & 0.43 & 0.52 & 0.68 \\
\hline Adopted & 2080 & & 0.4 & 0.6 & \\
\hline Calculated & 2130 & 0.67 & 0.81 & 1.25 & 1.59 \\
\hline Adopted & 2130 & & 0.8 & 1.25 & 1.6 \\
\hline
\end{tabular}

\section{Coastal Inundation}

Coastal inundation is land covered by sea water through a combination of storm effects, tide and wave setup plus any allowance for future sea-level rise. Coastal inundation due to these storm and atmospheric effects has been modelled by NIWA in 2019 [4]. This mapped the overland extent of coastal inundation for the whole Tauranga Harbour coastline of which Tauranga City occupies a small section of the eastern end. Land covered by water in each scenario is mapped using a four colour code to represent depth of inundation with the blue colours representing divisions less than one metre and orange representing anything over one metre depth from existing ground level to water surface. A sample mapping of three separate inundation scenarios is shown for the same location in Figure 2.

The study used a calibrated hydrodynamic model operating in 2D to simulate water levels. Boundary conditions applied were tidal levels and annual average river flows. Physical processes were input as parameters for wind, barometric pressure, surface conditions and bottom conditions and overland roughness conditions for the actual inundation. Table 2 lists specific input details. The model was calibrated for tidal elevations from 26 gauging sites and the output was validated against a storm event in January 2018.

Table 2: Inputs and outputs for inundation modelling.

\begin{tabular}{ll} 
Input parameter & Description \\
\hline Base tidal scenario & $\begin{array}{l}\text { Mean High water springs 7 (MHWS7) - } \\
\text { The elevation exceeded only by the } \\
\text { highest 7\% of all high tides. }\end{array}$ \\
Storm scenarios & $2 \%, 1 \%$ and $0.2 \%$ AEP \\
SLR & Scenarios as described in table 1
\end{tabular}




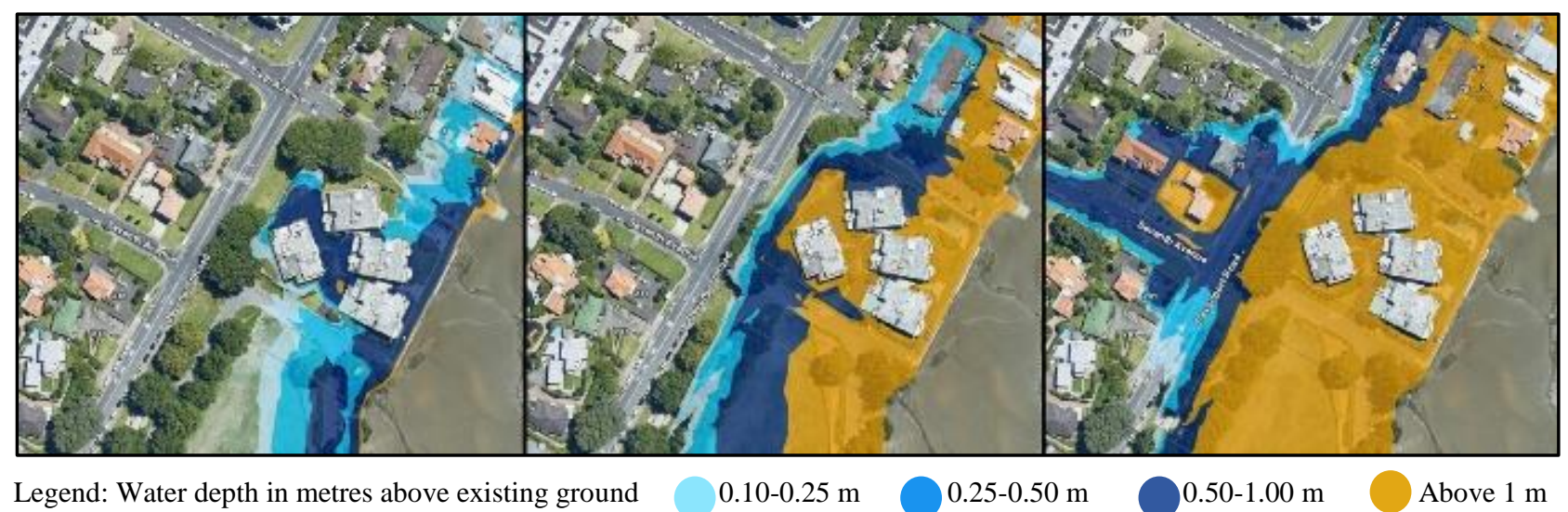

Figure 2: Inundation model output 2\% AEP storm 2020, 1\% storm with 0.6m SLR in 2080 (centre), $1 \%$ storm with 1.25 m SLR 2130.

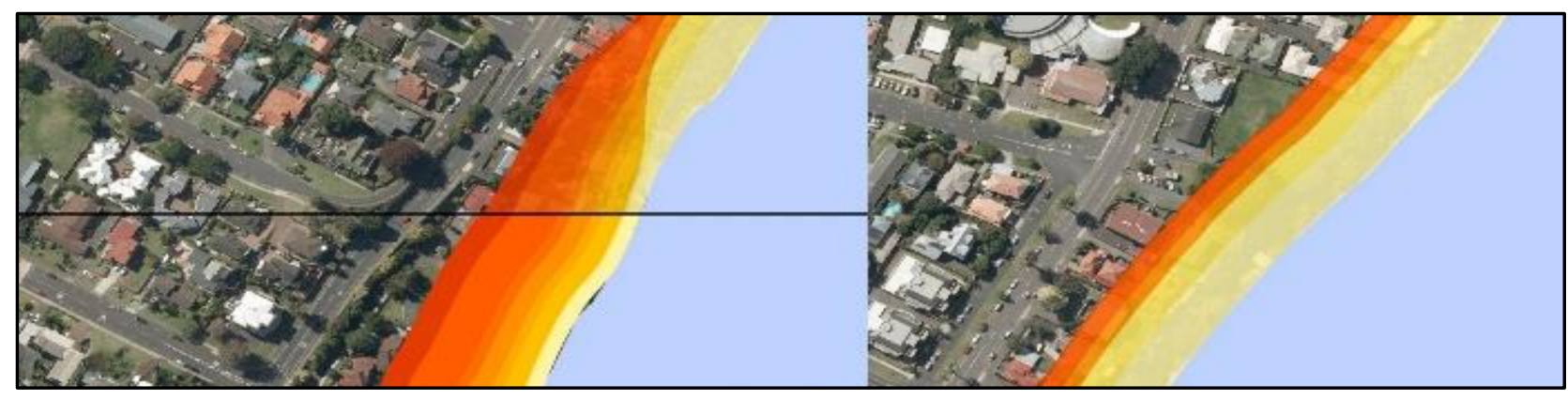

Figure 3: Erosion mapping of low-lying (left) and high cliff (right) coastline showing time and probability. Refer to Table 3 for legend.

\section{Coastal Erosion}

Tauranga's $88 \mathrm{~km}$ coastline includes $26 \mathrm{~km}$ of north facing coast open to the Pacific Ocean and $62 \mathrm{~km}$ of harbour coast. Inner harbour shores can be classified into $31 \mathrm{~km}$ of cliffs and $31 \mathrm{~km}$ of unconsolidated low-lying margins (see Figure 3). This creates three different erosion mechanisms which were modelled separately due to very different environmental drivers.

\section{Table 1: Inputs to the coastal erosion modelling.}

\begin{tabular}{llll}
$\begin{array}{l}\text { Input } \\
\text { parameter }\end{array}$ & Inner Harbour & Probabilities Mapped \\
\hline Coastline & $\begin{array}{l}\text { Historical aerial } \\
\text { photos 1943 }\end{array}$ & \\
SLR & $\begin{array}{l}\text { Scenarios as per } \\
\text { section 2.2 }\end{array}$ & \\
& Current & $\begin{array}{l}\text { Current } \\
\text { MSL }\end{array}$ & Likely \\
& & $0.4 \mathrm{~m}$ & Very unlikely \\
& SLR & Likely \\
& 2080 & $0.6 \mathrm{~m}$ & Likely \\
Mapped & & $0.6 \mathrm{~m}$ & Very unlikely \\
Scenarios & & $0.8 \mathrm{~m}$ & Likely \\
& 2130 & $1.25 \mathrm{~m}$ & Likely \\
& & $1.6 \mathrm{~m}$ & Very unlikely unlikely \\
\hline
\end{tabular}

Inner harbour erosion zones were defined by combining component parameters of slope stability, long term erosion rate, retreat due to sea level rise and short-term changes from storm erosion. Probabilities used for mapping erosion were adopted to reflect levels of confidence of "likely" and "very unlikely". Numerical probability for "likely" meaning there is a $66 \%$ probability that the line indicated on the map will be reached or exceeded. In the case of "very unlikely" there is a $5 \%$ probability, but it is still possible. The "very unlikely" line is always further landward than the "likely" case.

Table 3 provides the input data for erosion projection.

\section{Tsunami}

Coastal cities like Tauranga are particularly exposed to tsunami hazard as a large proportion of the population and much of the proposed growth is along the open coast. Tauranga is susceptible to both far-field and regional sources, with the Kermadec Trench to the north-east identified as the most likely source of a large tsunami which would pose a significant hazard.

Tsunami hazard was studied in 2013 [5] for the purposes of establishing evacuation zones shown in Figure 4. Modelling inputs and output are detailed in Table 4. In this case establishing the impact of a very large, low probability event was the primary objective. The data from this study was used to establish the tsunami hazard for the multi-hazard mapping so described in Table 5.

\section{Earthquake Shaking}

A Tauranga specific earthquake shaking analysis was completed to underpin liquefaction analysis and contribute a baseline input [7].

This probabilistic seismic hazard analysis (PSHA) adopted a model of soil conditions represented by Vs30 seismic shear wave velocity [8] which reflected the continuous geotechnical variation across the city. An earthquake rupture forecast was developed, and the seismic hazards then calculated in terms of 
peak ground acceleration (PGA) which was spatially mapped for return periods of $25,100,500,1,000$ and 3,030 years. The mean earthquake magnitude ranges from $\mathrm{M}_{\mathrm{w}} 6.1$ to 6.3 across this spectrum.

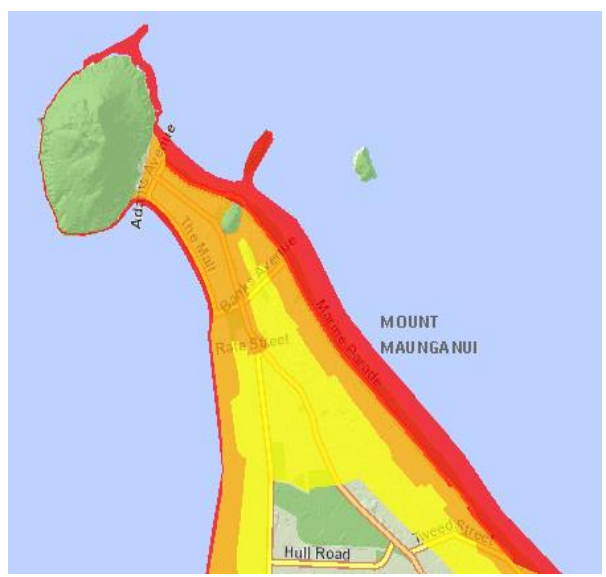

Figure 2: Tsunami evacuation zones adopted as hazard zones for this study. Orange represents approx. 1000 - 2500year return period. Yellow represents maximum credible event.

Table 2: Inputs and outputs for tsunami modelling.

\begin{tabular}{ll}
$\begin{array}{l}\text { Input } \\
\text { parameter }\end{array}$ & Description \\
\hline $\begin{array}{l}\text { Generating } \\
\text { source }\end{array}$ & $\begin{array}{l}\mathrm{M}_{\mathrm{W}} 9 \text { at 4-6 km depth over 300 km of southern } \\
\text { section of Kermadec Trench [6] }\end{array}$ \\
Water Levels & $\begin{array}{l}\text { Tide of } 0.8 \mathrm{~m} \text { above MSL representing } \\
\text { exceedance by 50\% of high tides }\end{array}$ \\
SLR & $\begin{array}{l}\text { SLR of 0.8 m was incorporated as alternate tidal } \\
\text { at the time of the tsunami }\end{array}$ \\
\hline Output & $\begin{array}{l}\text { 66 mins to shore from southern Kermadec } \\
\text { source. }\end{array}$ \\
\hline Pime & $\begin{array}{l}\text { Post impact estimation of 30 mins for majority of } \\
\text { inundation, 3-6 hours to maximum inland extent } \\
\text { after first arrival. }\end{array}$ \\
& $\begin{array}{l}\text { Approaches from approx. parallel to shore. } \\
\text { Nearshore islands cause localized refraction and } \\
\text { secondary wave focusing on middle third of the } \\
\text { 26 km coast. }\end{array}$ \\
\hline $\begin{array}{l}\text { Wave } \\
\text { characteristics }\end{array}$ &
\end{tabular}

Table 3: Definition of hazard zones for model calibration.

\begin{tabular}{|c|c|c|}
\hline $\begin{array}{l}\text { Evacuation } \\
\text { Zone }\end{array}$ & Description & Reference Tsunami scale \\
\hline $\begin{array}{l}\text { Red } \\
\text { High } \\
\text { Hazard }\end{array}$ & $\begin{array}{l}\text { Evacuated during } \\
\text { all scenarios } \\
\text { regardless of } \\
\text { size. }\end{array}$ & $\begin{array}{l}10 \mathrm{~m} \text { buffer from the coastal } \\
\text { edge }\end{array}$ \\
\hline $\begin{array}{l}\text { Orange } \\
\text { Medium } \\
\text { hazard }\end{array}$ & $\begin{array}{l}\text { Evacuation in } \\
\text { most if not all } \\
\text { official warnings }\end{array}$ & $\begin{array}{l}\text { Inundated under shoreline } \\
\text { wave of } 10 \mathrm{~m} \text {. This equates to } \\
\text { a return period of } 1,000-2,500 \\
\text { years }\end{array}$ \\
\hline $\begin{array}{l}\text { Yellow } \\
\text { Low } \\
\text { Hazard }\end{array}$ & $\begin{array}{l}\text { Likely extent of } \\
\text { inundation under } \\
\text { max credible } \\
\text { event }\end{array}$ & $\begin{array}{l}\text { Area inundated under } \\
\text { maximum credible tsunami. } \\
\text { Return period in excess of } \\
2,500 \text { years }\end{array}$ \\
\hline
\end{tabular}

\section{Liquefaction}

Liquefaction is an earthquake driven process where shaking increases the water pressure in some types of soil resulting in temporary loss of strength which causes significant land and building damage through settlement and horizontal ground movement. Liquefaction was mapped by ground damage projections based on soil type, water level and ground shaking. The damage map represented both free-field settlement and lateral spreading conditions showing three ground damage divisions of none-to-minor, minor-to-moderate and moderateto-severe. Input parameters adopted for liquefaction are listed in Table 6.

Table 4: Parameters for the liquefaction study.

\begin{tabular}{|c|c|}
\hline Input parameter & Description \\
\hline Seismic hazard & $\begin{array}{l}\text { A city specific seismic assessment PSHA } \\
\text { was prepared }\end{array}$ \\
\hline \multirow{2}{*}{$\begin{array}{l}\text { Ground water } \\
\text { levels }\end{array}$} & $\begin{array}{l}\text { Current ground water surface levels used in } \\
\text { current liquefaction modelling }\end{array}$ \\
\hline & $\begin{array}{l}\text { Current }+1.25 \mathrm{~m} \text { used as ground water } \\
\text { surface for } 2130 \text { scenarios }\end{array}$ \\
\hline \multirow{4}{*}{$\begin{array}{l}\text { Earthquake return } \\
\text { periods analysed }\end{array}$} & $\begin{array}{l}25 \text {-yr representing serviceability limit state } \\
\text { requirements }\end{array}$ \\
\hline & $\begin{array}{l}100-y r \text { and } 250-y r \text { showing interim } \\
\text { liquefaction levels }\end{array}$ \\
\hline & $\begin{array}{l}500 \text {-yr representing ultimate limit state } \\
\text { requirements }\end{array}$ \\
\hline & $\begin{array}{l}1,000-y r \text { representing full liquefaction } \\
\text { mobilization condition }\end{array}$ \\
\hline \multirow{2}{*}{$\begin{array}{l}\text { Ground water } \\
\text { levels analysed }\end{array}$} & Current water level at $50 \%$ probability \\
\hline & 100 -yr projection at $+1.25 \mathrm{~m}$ \\
\hline
\end{tabular}

\section{Landslides}

Tauranga is a city of two geomorphic halves. The western city is dominated by ignimbrite and volcanic ash ridges while the east is low lying sandy coastal plain. It is the western section that exhibits landslides. Studies carried out in 2001 [9] established a methodology for hazard rating according to the slope, and this forms the basis of Tauranga hazard mapping at present.

The 2001 study used aerial photos to identify more than 2,000 relic slip features and establish a register of 2,000 head scarps and 400 slope debris features. Analysis of typical landslide features provided a frequency distribution of slip and head scarp attributes that were translated into Tauranga city planning rules which are summarized in Table 7.

\section{Table 5: Current parameters for the landslide hazard} evaluation.

\begin{tabular}{ll} 
Slope & Associated Hazard \\
\hline 2H:1V or steeper & High slip hazard \\
4H:1V from head-scarp & Debris runout zone hazard \\
location & Head-scarp collapse hazard \\
3H:1V from toe location & P \\
\hline
\end{tabular}

\section{Flooding}

Flooding due to heavy rainfall is a regular occurrence in Tauranga. The city is characterized by 24 catchments that are predominantly residential. Portions of the lower catchments are also used for water management, passive recreation and conservation. The upper portion of large catchments are frequently outside of the Tauranga boundary and undeveloped. 
Modelling these catchments was carried out from 2014 to 2020 using coupled models to simulate the multiple environments present in the catchment. The input parameters are shown in Table 8 and the combined output of all catchments is mapped on the TCC GIS [10]. The model was validated using flood incident reports for a storm event that occurred in April 2013 [11].

Table 6: Parameters for the flood modelling.

\begin{tabular}{ll} 
Input parameter & Description \\
\hline \multirow{3}{*}{ City catchments } & 24 total ranging $2 \mathrm{~km}^{2}$ to $56 \mathrm{~km}^{2}$ \\
& $\begin{array}{l}\text { Total area183 } \mathrm{km}^{2} \quad \text { Highest elevation } \\
930 \mathrm{~m}\end{array}$ \\
\hline & $\begin{array}{l}10,50,100 \text {-year storm. Present climate and } \\
\text { development }\end{array}$ \\
Rainfall scenarios & $\begin{array}{l}10 \text { and } 50 \text {-year storm. Projected } 2055 \\
\text { climate conditions } \\
\text { 50, 100 and 500-year storm. Projected 2130 } \\
\text { climate conditions }\end{array}$ \\
\hline
\end{tabular}

\section{MULTI-HAZARD EXPOSURE MAPPING IN GIS}

\section{Hazard Aggregation}

The aggregated hazard at each point of the city was achieved by combining output from each individual hazard into a summative multi-hazard model. Each point is rated according to the accumulated number and scale of individual hazards, effectively providing a multi-hazard exposure for that point. The resultant map provides a visual interpretation of the accumulated hazard. This research appears unique in the large number of hazards aggregated into this multi-hazard map. Steps in this process:-

1. Complete probabilistic hazard assessments adopting consistent probabilities and timescales to enable direct aggregation $\left(\mathrm{H}_{1}-\mathrm{H}_{\mathrm{n}}\right.$ and $\left.\mathrm{HSLR}_{\mathrm{SLR}}\right)$

2. Define exposure levels to each hazard and apply a 10-point scale to be adopted as a hazard schema $\left(\mathrm{HS}_{1}-\mathrm{HS}_{\mathrm{n}}\right.$ and HSSLR). Application of an additional schema factor will be necessary for hazards mapped with different return periods and timescales $\left(\mathrm{SF}_{1}-\mathrm{SF}_{\mathrm{n}}\right.$ and $\left.\mathrm{SF}_{\mathrm{SLR}}\right)$

3. Define weighting coefficient to normalize individual hazards for balanced aggregation $\left(\mathrm{N}_{1}-\mathrm{N}_{\mathrm{n}}\right.$ and $\left.\mathrm{N}_{\mathrm{SLR}}\right)$

4. Sum normalized schema to obtain numerical representation of aggregated exposure ( $\left.\mathrm{E}_{\mathrm{HM}}\right)$

5. Geospatially map multi-hazard ratings in GIS

$$
E_{H M}=\sum_{H_{1}}^{H_{\mathrm{n}}} H S \times S F \times N
$$

where, $E_{H M}=$ Exposure sum for all hazards

$H S=$ Hazard Schema

$S F=$ Schema Factor

$N=$ Normalisation

$H_{n}=$ Individual hazard (specific hazard represented by the subscript; e.g. hazard due to SLR is shown as $H_{S L R}$ )

\section{Identification of Pilot Zone for the Study}

A sub-area of Tauranga city has been adopted as a pilot area for this study (see Figure 5). This $25 \mathrm{~km}^{2}$ area represents the full suite of hazards, landforms, infrastructure and population applicable to Tauranga's total of $135 \mathrm{~km}^{2}$. The area consists of the central business district (CBD) and extends southward through the areas being considered for future residential intensification. It is this southern area that is prone to landslides. The area extends northwards far enough to represent both open coast and inner harbour erosion. Mt. Maunganui itself is not included in the mapping at the time of publication.

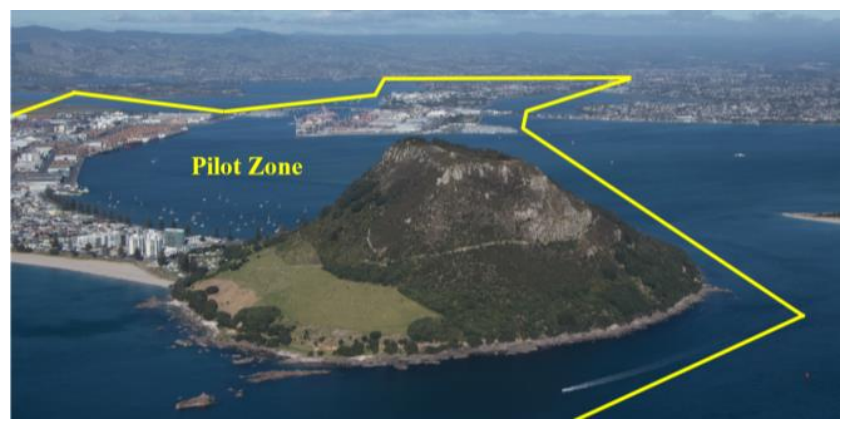

Figure 3: Plan of the pilot study area.

Table 7: Hazard Schema for each hazard showing defining events.

Events defining schema points assignment

\begin{tabular}{|c|c|c|c|c|}
\hline Hazard & High (10) & Medium & Low (1) & $\begin{array}{l}\text { Max. } \\
\text { extent }\end{array}$ \\
\hline \multirow{2}{*}{$\begin{array}{l}\text { Sea level rise } \\
\left(\mathrm{HS}_{\mathrm{SLR}}\right)\end{array}$} & \multirow{2}{*}{$\begin{array}{l}\text { Up to } 0.4 \mathrm{~m} \\
\text { SLR }\end{array}$} & $\begin{array}{l}50 \text {-year } \\
\text { projection }\end{array}$ & $\begin{array}{l}100-y r \\
\text { projection }\end{array}$ & $\begin{array}{l}100-y r \\
\text { projection }\end{array}$ \\
\hline & & $0.4-0.8 \mathrm{~m}$ & $1.25-1.6 \mathrm{~m}$ & 1.6m SLR \\
\hline \multirow{3}{*}{$\begin{array}{l}\text { Inundation } \\
\text { from Storm } \\
\text { Surge }\left(\mathrm{HS}_{\mathrm{I}}\right)\end{array}$} & $\begin{array}{l}10-\mathrm{yr} \\
\text { projection }\end{array}$ & $\begin{array}{l}50-\mathrm{yr} \\
\text { projection }\end{array}$ & $\begin{array}{l}100-y r \\
\text { projection }\end{array}$ & $\begin{array}{l}100-y r \\
\text { projection }\end{array}$ \\
\hline & $0.0 \mathrm{~m} \mathrm{SLR}$ & $0.6 \mathrm{~m} \mathrm{SLR}$ & $1.25 \mathrm{~m}$ SLR & $1.25 \mathrm{~m}$ SLR \\
\hline & $\begin{array}{l}1 \% \text { AEP } \\
\text { storm }\end{array}$ & $\begin{array}{l}1 \% \text { AEP } \\
\text { storm }\end{array}$ & $\begin{array}{l}1 \% \text { AEP } \\
\text { storm }\end{array}$ & $\begin{array}{l}1 \% \text { AEP } \\
\text { storm }\end{array}$ \\
\hline \multirow{3}{*}{$\begin{array}{l}\text { Coastal } \\
\text { erosion } \\
\left(\mathrm{HS}_{\mathrm{C}}\right)\end{array}$} & $\begin{array}{l}10-\mathrm{yr} \\
\text { projection }\end{array}$ & \multirow{3}{*}{$\begin{array}{l}50-\mathrm{yr} \\
\text { projection } \\
0.6 \mathrm{~m} \text { SLR } \\
66 \% \text { AEP } \\
\text { (Likely) }\end{array}$} & \multirow{3}{*}{$\begin{array}{l}100-y r \\
\text { projection } \\
1.25 \mathrm{~m} \mathrm{SLR} \\
66 \% \text { AEP } \\
\text { (Likely) }\end{array}$} & \multirow{3}{*}{$\begin{array}{l}100-\mathrm{yr} \\
\text { projection } \\
1.25 \mathrm{~m} \text { SLR } \\
66 \% \text { AEP } \\
\text { (Likely) }\end{array}$} \\
\hline & $0.0 \mathrm{~m}$ SLR & & & \\
\hline & $\begin{array}{l}5 \% \text { AEP } \\
\text { (Highly } \\
\text { unlikely) }\end{array}$ & & & \\
\hline $\begin{array}{l}\text { Tsunami } \\
\left(\mathrm{HS}_{\mathrm{T}}\right)\end{array}$ & $\begin{array}{l}\text { Red } \\
\text { evacuation } \\
\text { zone }\end{array}$ & $\begin{array}{l}\text { Orange } \\
\text { evacuation } \\
\text { zone }\end{array}$ & $\begin{array}{l}\text { Yellow } \\
\text { evacuation } \\
\text { zone }\end{array}$ & $\begin{array}{l}\text { Yellow } \\
\text { zone inland } \\
\text { extreme }\end{array}$ \\
\hline \multirow{4}{*}{$\begin{array}{l}\text { Liquefaction } \\
\left(\mathrm{HS}_{\mathrm{L}}\right)\end{array}$} & \multirow{4}{*}{$\begin{array}{l}\text { Moderate- } \\
\text { severe } \\
\text { ground } \\
\text { damage } \\
0.0 \mathrm{~m} \text { SLR } \\
0.2 \% \text { AEP }\end{array}$} & \multirow{4}{*}{$\begin{array}{l}\text { Minor - } \\
\text { moderate } \\
\text { ground } \\
\text { damage } \\
0.0 \mathrm{~m} \mathrm{SLR} \\
0.2 \% \text { AEP }\end{array}$} & $\begin{array}{l}100-y r \\
\text { projection }\end{array}$ & $\begin{array}{l}100-y r \\
\text { projection }\end{array}$ \\
\hline & & & $\begin{array}{l}\text { Minor - } \\
\text { moderate }\end{array}$ & $\begin{array}{l}\text { Extent of } \\
\text { minor-mod }\end{array}$ \\
\hline & & & $1.25 \mathrm{~m} \mathrm{SLR}$ & $1.25 \mathrm{~m} \mathrm{SLR}$ \\
\hline & & & $0.2 \%$ AEP & $0.2 \%$ AEP \\
\hline $\begin{array}{l}\text { Landslide } \\
\left(\mathrm{HS}_{\mathrm{LS}}\right)\end{array}$ & $\begin{array}{l}\text { Within } \\
\text { slope zone } \\
2 \mathrm{~h}: 1 \mathrm{v}\end{array}$ & \multicolumn{2}{|c|}{$\begin{array}{c}\text { Outside } 2 \mathrm{~h}: 1 \mathrm{v} \text { zone } \\
\text { and } \\
\text { inside } 3 \mathrm{~h}: 1 \mathrm{v} \text { upslope } \\
\text { or } \\
\text { inside } 4 \mathrm{~h}: 1 \mathrm{v} \text { runout side }\end{array}$} & $\begin{array}{l}\text { Outside of } \\
\text { defined } \\
\text { zones }\end{array}$ \\
\hline \multirow{3}{*}{$\begin{array}{l}\text { Flooding } \\
\left(\mathrm{HS}_{\mathrm{F}}\right)\end{array}$} & $\begin{array}{l}\text { Current } 1 \mathrm{~m} \\
\text { depth }\end{array}$ & \multirow{3}{*}{$\begin{array}{l}\text { Current max } \\
0.0 \mathrm{~m} \text { SLR } \\
1 \% \text { AEP } \\
\text { storm }\end{array}$} & $\begin{array}{l}100-y r \\
\text { projection }\end{array}$ & $\begin{array}{l}100-y r \\
\text { projection }\end{array}$ \\
\hline & $0.0 \mathrm{~m}$ SLR & & $1.25 \mathrm{~m} \mathrm{SLR}$ & $1.25 \mathrm{mSLR}$ \\
\hline & $\begin{array}{l}1 \% \text { AEP } \\
\text { storm }\end{array}$ & & $\begin{array}{l}1 \% \text { AEP } \\
\text { storm }\end{array}$ & $\begin{array}{l}1 \% \text { AEP } \\
\text { storm }\end{array}$ \\
\hline
\end{tabular}

\section{Define Hazard Schema (HS)}

It is necessary to assign a numerical score representing the exposure level at each spatial point to each hazard. A 10-point scale adequately represented the full range of exposure while enabling considered variations based on the local conditions and parameters of the hazard quantification study. Schema assignments are detailed in Table 9. Areas already exposed to the hazard at a low return period event were considered high exposure. Areas at the outer extents of exposure under a hazard scenario of $1 \%$ AEP and $1.25 \mathrm{~m}$ SLR were considered low exposure. An example using the inundation shown in Figure 2 
would assign a high hazard exposure value (9-10) to all areas inundated in a $2 \%$ AEP storm in a 2020 event, shown in dark blue. A low value would be assigned at the $1 \%$ storm with $1.25 \mathrm{~m}$ SLR 2130. Graduation of the exposure value between one and ten can be assigned according to intermediate depths of inundation, intermediate event magnitudes and SLR.

Earthquake shaking and volcanic ashfall were not individually mapped as there was minimal variation across the city and so did not provide differentiation in the multi-hazard map.

\section{Define Schema Factor (SF) for Probability Variations}

Calculation of adjustment factors to the HS to account for different return periods where these were not aligned adequately from the hazard quantification study. In this study two hazards incorporated probabilities that required a schema factor. Tsunami exposure was obtained from low frequency event estimates and liquefaction adopted a $0.2 \%$ AEP event to better represent the spatial potential of liquefaction in an earthquake. These are shown in Table 10.

Table 8: Schema factors (SF) for return period adjustment.

$\begin{array}{cccc}\text { Hazard } & \text { Schema } & \text { Hazard study } & \text { Basis of adjustment } \\ & \text { Factor (SF) } & \text { return period } & \text { calculation }\end{array}$

\begin{tabular}{|c|c|c|c|}
\hline \multirow{2}{*}{$\begin{array}{l}\text { Tsunami } \\
\left(\mathrm{SF}_{\mathrm{T}}\right)\end{array}$} & \multirow[t]{2}{*}{0.5} & $\begin{array}{l}1,000 \text { to } \\
2,500 \text {-year } \\
\text { Orange }\end{array}$ & $\begin{array}{l}\text { Available data is based } \\
\text { on long return period } \\
\text { high magnitude events } \\
\text { established for } \\
\text { evacuation purposes. }\end{array}$ \\
\hline & & $\begin{array}{l}>2,500 \text {-year } \\
\text { Yellow zone }\end{array}$ & $\begin{array}{l}\text { Factor was derived from } \\
\text { ratio of PGA established } \\
\text { for Tauranga through } \\
\text { the PSHA }\end{array}$ \\
\hline $\begin{array}{l}\text { Liquefact } \\
\text { ion }\left(\mathrm{SF}_{\mathrm{L}}\right)\end{array}$ & 0.75 & 500-year & $\begin{array}{l}500 \text {-year adopted to } \\
\text { give extent of } \\
\text { liquefaction in post- } \\
\text { activation condition. } \\
\text { Factor was derived from } \\
\text { ratio of PGA established } \\
\text { through the PSHA }\end{array}$ \\
\hline
\end{tabular}

\section{Determine Hazard Normalization (N) for Aggregation}

Seven factors have been recognised as important aspects of events in regard to their potential hazard [12]. These are magnitude, frequency, duration, areal extent, speed of onset, spatial dispersion and temporal spacing. For each hazard these factors are assessed and weighted and shown in Table 11 with the exclusion of magnitude, frequency and temporal spacing which are already included in the specific hazard mapping quantification.

\section{Geospatial Mapping Multi-Hazard Ratings using GIS}

Mapping of aggregated multi-hazards exposure values was carried out using GIS providing a spatially correct all-hazard exposure rating for all points of the pilot zone. The resultant map provides a visual interpretation of multi-hazard exposure. Numerical output of $E_{H M}$ was represented through a five-level colour map. A maximum exposure value would identify a point impacted by all hazards at low return periods. These exposures were represented by hexagonal shapes of $250 \mathrm{~m}$ diameter in order to represent a defined area without being so detailed as to identify individual properties.
Table 9: Hazard normalization coefficient $(N)$.

\begin{tabular}{|c|c|c|c|c|c|}
\hline \multirow{3}{*}{ Hazard } & & $\begin{array}{c}\text { Speed of } \\
\text { onset }\end{array}$ & Duration & $\begin{array}{c}\text { Areal } \\
\text { extent }\end{array}$ & $\begin{array}{c}\text { Spatial } \\
\text { dispersion }\end{array}$ \\
\hline & & $\begin{array}{c}\text { Speed } \\
\text { event } \\
\text { becomes } \\
\text { hazard }\end{array}$ & $\begin{array}{c}\text { How long } \\
\text { event will } \\
\text { persist }\end{array}$ & $\begin{array}{l}\text { Spatial } \\
\text { extent } \\
\text { likely }\end{array}$ & $\begin{array}{c}\text { Spatial } \\
\text { predictability }\end{array}$ \\
\hline & $\mathbf{N}$ & $\begin{array}{l}1 \text {-slow } \\
\text { fast-5 }\end{array}$ & $\begin{array}{l}1 \text {-short } \\
\text { long-5 }\end{array}$ & $\begin{array}{l}\text { 1-limited } \\
\text { spread-5 }\end{array}$ & $\begin{array}{l}\text { 1-diffuse } \\
\text { conc-5 }\end{array}$ \\
\hline $\begin{array}{l}\text { Sea level rise } \\
\left(\mathrm{N}_{\mathrm{SLR}}\right)\end{array}$ & 0.16 & 1 & 5 & 5 & 5 \\
\hline $\begin{array}{l}\text { Inundation } \\
\left(\mathrm{N}_{\mathrm{I}}\right)\end{array}$ & 0.11 & 2 & 5 & 2 & 3 \\
\hline $\begin{array}{l}\text { Coastal } \\
\text { erosion }\left(\mathrm{N}_{\mathrm{C}}\right)\end{array}$ & 0.12 & 2 & 5 & 2 & 3 \\
\hline Tsunami $\left(\mathrm{N}_{\mathrm{T}}\right)$ & 0.15 & 4 & 2 & 4 & 5 \\
\hline $\begin{array}{l}\text { Liquefaction } \\
\left(\mathrm{N}_{\mathrm{L}}\right)\end{array}$ & 0.16 & 5 & 1 & 5 & 5 \\
\hline $\begin{array}{l}\text { Landslides } \\
\left(\mathrm{N}_{\mathrm{LS}}\right)\end{array}$ & 0.14 & 5 & 5 & 2 & 2 \\
\hline Flooding $\left(\mathrm{N}_{\mathrm{F}}\right)$ & 0.13 & 3 & 3 & 3 & 4 \\
\hline
\end{tabular}

\section{Usability Objective of Mapping}

Output that is easily usable and quickly understandable while maintaining appropriate levels of accuracy is key to this tool being adopted. Table 12 sets out elements that contribute and how they were achieved.

\section{Table 10: Selected elements of usability showing objective and methodology.}

Usability subobjective

Method adopted

\begin{tabular}{ll}
\hline Visually uncluttered & $\begin{array}{l}\text { Five colour rating system to produce a } \\
\text { heatmap of exposure }\end{array}$ \\
\hline $\begin{array}{l}\text { Clear indication of } \\
\text { relative exposures } \\
\text { spatially }\end{array}$ & $\begin{array}{l}\text { Limiting to five colours maintains clarity } \\
\text { Vertical (3D) representation of exposure } \\
\text { will also enhance readability }\end{array}$ \\
\hline $\begin{array}{l}\text { Easy location } \\
\text { identification }\end{array}$ & $\begin{array}{l}\text { Underlying City map visible through } \\
\text { exposure heatmap } \\
\text { 3D will aid location recognition through } \\
\text { topographical features }\end{array}$ \\
\hline $\begin{array}{l}\text { More depth of data } \\
\text { available on } \\
\text { demand }\end{array}$ & $\begin{array}{l}\text { Provide exposure chart for any space } \\
\text { providing the percentage of impact each } \\
\text { hazard applies to that location }\end{array}$ \\
\hline
\end{tabular}

\section{Evaluation of Mapping}

The output mapping as shown in Figure 6 is visibly simple and identification of various exposure areas in this pilot zone is straight forward. The single point exposure chart in Figure 7 provides excellent clarification and will be useful to develop for community education.

Verification of the multi-hazard mapping was carried out by comparison with historical mapping. City planning rules have established hazard zones for several decades and the exclusion zones and building restriction lines match well with the high and extreme hazard exposures identified in this multi-hazard mapping. Inspection of individual hazard mapping also confirms alignment of the multi-hazard exposure. 




Figure 4: Multi-hazard exposure map for the pilot zone.

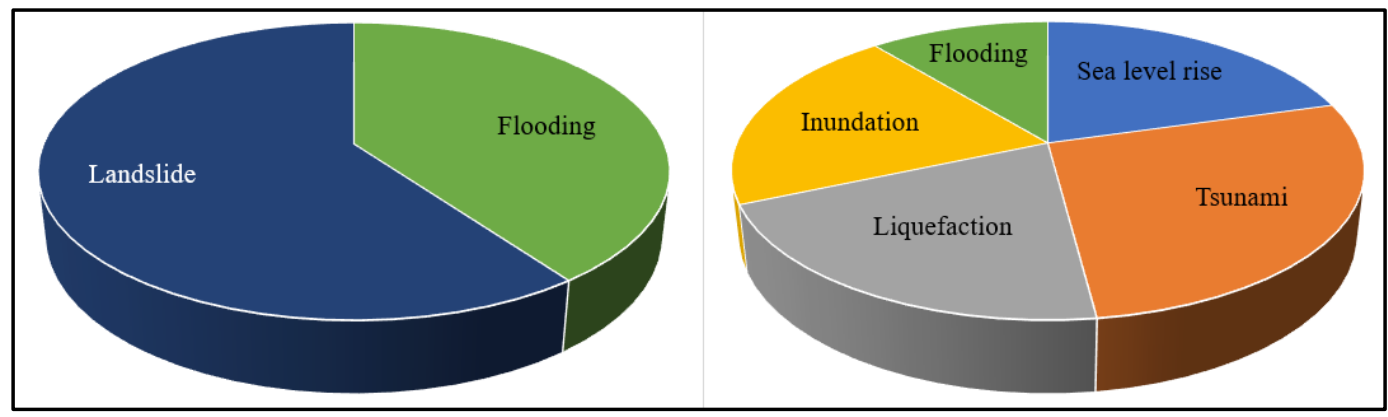

Figure 5: Single point exposure contribution chart from points A (left) and B in Figure 6.

The successfully achieved visual output, substantiated by the integrated hazard data supports the continuation of research to include the entire city in the multi-hazard mapping and to incorporate a $3 \mathrm{D}$ visualization option.

\section{Areas for Further Research}

Completion and incorporation of new hazard data will enhance the hazard representation accuracy. A new probabilistic landslide mapping is due for completion in 2021 which will remove the application of a hazard schema factor (SF) to the landslide hazard. Hazards with a longer return period but higher consequential damage could be factored into the hazard mapping and subsequent growth planning.

\section{CONCLUSIONS}

Multi-hazard mapping effectively identified hazard exposures to support urban growth planning in the coastal city of Tauranga. Each part of the city was rated according to the overall number and scale of individual hazards and spatially mapped to provide a clear visual interpretation of the exposure at any part of the city. Direct comparisons across the city are a critical informant to city growth planning and targeted investment in infrastructure resilience building. This research provides evidence that multi-hazard mapping will fulfil that need.
The mapping showed that the highest aggregated hazard exposure areas in Tauranga are along the coast. As is common with many beach resort towns this corresponds with the most popular living areas. Lower hazard areas suitable for urban growth are on the slightly elevated peninsulas. It can also be seen that landslide potential increases exposure further from the coast and along the peninsular margins, thus constraining Tauranga's growth on all sides.

A key to effective mapping was high-resolution quantification of the many natural hazards. As this is a coastal city, sea level rise projections impact every hazard except landslides. A common calibration point across all hazards was established at $1 \%$ AEP event projected 100 years to 2130 incorporating $1.25 \mathrm{~m}$ sea level rise provided for reliable aggregation. Aggregated mapping of seven natural hazard appears unique in the number of hazards represented.

The resultant map provides a reliable visual interpretation of the aggregated hazard levels to help decision makers and aide in communicating risks to the public. The graphic representation is a powerful tool that can also be used for building community resilience through education and extended to asset exposure to enable infrastructure strengthening for resilience. Based on this successful pilot it is proposed to expand the map to the whole city and incorporate improved 3D graphic visualization. 


\section{REFERENCES}

1 Simonson T and Hall G (2019). "Vulnerable: The Quantum of Local Government Infrastructure Exposed to Sea Level Rise". Local Government New Zealand, 43pp. https://www.lgnz.co.nz/assets/Uploads/d566cc5291/47716 -LGNZ-Sea-Level-Rise-Report-3-Proof-FINALcompressed.pdf

2 Stephens S (2017). "Tauranga Harbour Extreme Sea Level Analysis". NIWA Client Report No: 2017035HN, National Institute of Water and Atmospheric Research (NIWA) Ltd, Hamilton, NZ, 47pp. https://www.tauranga.govt.nz/Portals/0/data/living/natural hazards/files/niwa_sea_level_analysis_report.pdf

3 Ackerley D, Bell RG, Mullan AB and McMillan H (2013). "Estimation of regional departures from global-average sea-level rise around New Zealand from AOGCM simulations". Weather and Climate, 33: 2-22. https://doi.org/10.2307/26169734

4 Reeve G, Stephens S and Wadhwa S (2019). "Tauranga Harbour Inundation Modelling”. NIWA Client Report No: 2018269HN, National Institute of Water and Atmospheric Research (NIWA) Ltd, Hamilton, NZ, 127pp. https://docs.niwa.co.nz/library/public/2018269HN.pdf

5 Tonkin and Taylor Limited (2013). "Tauranga Tsunami Inundation Modelling for Tauranga City Council". Tonkin and Taylor, NZ, 25pp + Appendices.
6 Beban JG, Cousins WJ, Wang X and Becker J (2012) "Modelling of the Tsunami Risk to Papamoa, Wairakei and Te Tuтu Assuming an Altered Ground Level due to Development of Wairakei and Te Tumu and the Implications for the Smart Growth Strategy".

7 Bradley B (2019). "Regional Ground Motion Hazard for Liquefaction and Landslide Assessment, Tauranga City". Bradley Seismic Limited, Christchurch, NZ, 15pp.

8 Foster K, Bradley BA, McGann CR and Wotherspoon LM (2019). "A Vs30 map for New Zealand based on geologic and terrain proxy variables and field measurements". Earthquake Spectra, 35(4): 1865-1897. https://doi.org/10.1193/121118EQS281M

9 Bell DH, Richards LR and Thomson R (2001). "Relic Slip Verification Study - Tauranga District Council Environs". Rock Engineering Consultant, Christchurch, NZ, 70pp.

10 Tauranga City Council (2020). "Flood Hazard GIS Database".

https://mapi.tauranga.govt.nz/Html5/index.html?viewer= Mapi (Accessed April 2021)

11 Aurecon (2013). "Matua Peninsula Mike Flood Model April 2013 Validation Report". Internal Report, Aurecon New Zealand Ltd, NZ.

12 Blackstock HAI (2002). "Hazard Mapping in Hamilton City, New Zealand". Master of Science Thesis, Earth Science, University of Waikato, Hamilton, NZ, 439pp. 